\title{
ASSESSMENT OF HABITAT CONDITIONS USING SELF-ORGANIZING FEATURE MAPS FOR REINTRODUCTION/INTRODUCTION OF ALDROVANDA VESICULOSA L. IN POLAND
}

\author{
PIOTR KOSIBA ${ }^{1}$, LUCYNA MRÓZ ${ }^{1}$, RYSZARD KAMIŃSKI ${ }^{2}$ \\ ${ }^{1}$ Departament of Ecology, Biogeochemistry and Environmental Protection, \\ Institute of Plant Biology, Wroclaw University \\ Kanonia 6/8, 50-328 Wrocław, Poland \\ kosibap@biol.uni.wroc.pl \\ ${ }^{2}$ Botanical Garden, Wrocław University \\ Sienkiewicza 23, 50-335 Wrocław, Poland
}

(Received: April 22, 2010. Accepted: February 23, 2011)

\begin{abstract}
The study objects were Aldrovanda vesiculosa L., an endangered species and fifty five water sites in Poland. The aim of the present work was to test the Self-Organizing Feature Map in order to examine and predict water properties and type of trophicity for restoration of the rare plant. Descriptive statistical parameters have been calculated, analysis of variance and cluster analysis were carried out and SOFM model has been constructed for analysed sites. The results of SOFM model and cluster analysis were compared. The study revealed that the ordination of individuals and groups of neurons in topological map of sites are similar in relation to dendrogram of cluster analysis, but not identical. The constructed SOFM model is related with significantly different contents of chemical water properties and type of trophicity. It appeared that sites with $A$. vesiculosa are predominantly distrophic and eutrophic waters shifted to distrophicity. The elevated model showed the sites with chemical properties favourable for restoration the species. Determined was the range of ecological tolerance of the species in relation to habitat conditions as stenotopic or relatively stenotopic in respect of the earlier accepted eutrophic status. The SOFM appeared to be a useful technique for ordination of ecological data and provides a novel framework for the discovery and forecasting of ecosystem properties constituting a validation of the SOFM method in this type of studies.
\end{abstract}

KEY WORDS: SOFM, SOM, ecological modelling, Aldrovanda vesiculosa, ecological restoration, reintroduction, introduction.

\section{INTRODUCTION}

Numerous areas of wild nature were in a considerable degree partially or completely destroyed in result of human activity. The need of reconstruction of the nature habitat properties changed by man, as well as plants and animals caused the increase of ecological restoration and reintroduction or introduction of species as tools in biotic conservation (Pullin 2002) and in environmental management (Pullin and Steward 2006).

Natural and artificial enrichment of water bodies by mineral and organic substances usually causes eutrophication. Water ecosystems make the significant part in all aspects of environmental pollution, which are for many years a problem in many countries (Hutchinson 1975; Smith et al. 1999; Bell and Treshow 2002). Changes of water proper- ties are the reason of die out of various organisms, including plants. This process intensified in the second half of the 20th century as a result of industrial, economic activity and urbanization of areas. The effect of anthropopressure is the diminution of plant species number and the disappearance of many sites, once frequently met and today rare. They are revealed by "List of Dying Out and Endangered Plants" (Zarzycki and Wojewoda 1986) as well as "The Polish Red Books of Plants (Kaźmierczakowa and Zarzycki 2001; Mirek et al. 2006), and also the home lists of various countries from all continents (Kamiński 2006). One of the vanishing plant species is Aldrovanda vesiculosa, which, for a dozen of years, is threatened by die out (E endangered) and it is a species needing active conservation (Mirek et al. 2006). Because of the high rate of disappearance of $A$. vesiculosa in Poland during several dozen of 
years undertaken were works and investigations heading towards reintroduction/introduction of this species (Kamiński 1995, 2006).

Nowadays, particular attention is being paid to search of methods and solutions enabling higher verification possibilities of study results. Researchers use a lot of numerical methods, mainly classical methods, but also techniques based on neural networks (NN). This methods aim at recognizing the regularities occurring in phenomenons and processes remaining under the influence of the main reasons (systematic component) and indirect ones (accidental component) (Sokołowski 2010). The evaluation of properties of the environmental systems, here the ecological ones, by means of various mathematical descriptions can be used both for cognitive and practical aims. The connection of these two aims for preparation of models of natural phenomena and processes used not only for description, but also to foresee the situations in environment. The application and value of such models in ecology is a general one and strives for total statements, but their use depends mainly in analyzing the particular cases (Kosiba 2010). Apart from classical statistical-mathematical methods for evaluation of the natural environment, considered as ecological phenomena and processes taking place in it, used are also the neural networks (NNs), more specifically the artificial neural networks (ANNs). There are many different architectures of ANNs (Hecht-Nielsen 1990) and one of them are the Self-Organizing Features Maps (SOFM). In an attempt to cluster and pattern complex nonlinear data, Kohonen (2001) designed ANN for self-organizing mapping based on an unsupervised learning algorithm. SOFM modelling is being increasingly applied in various aspects of science, including the environmental field and applications to ecology are quite recent. In fact, the first references about the potential use of ANNs has not been found in ecological literature before the early 90s (Colasanti 1991; Özesmi et al. 2006). A few years later Edwards and Morse (1995) and Lek and Guegan (1999), pointed that ANNs could have played an important role in computer-aided biodiversity research, and the first ecological applications appeared. Recently, the application of ANNs to environmental studies has attracted great interest, and the first work-shop on the application of artificial neural networks in ecological modelling in Toulouse in the year 1998 was organized (Lek and Guegan 1999). A literature review of ANNs application in environmental research include, among others the papers of Lek and Guegan (1999), Özesmi et al. (2006) and Kosiba (2010). According to Chon et al. (1996), Giraudel and Lek (2001), ANNs are a good tool and are used both to ordinate and to classify ecological data. According to Tadeusiewicz (1993, 1998), neural networks are considered as one of the methods for regression and classification problems, and are used in a wide range of applications to solve various problems. NNs draws attention to the application of ANNs in biotechnology and biomaterials, which offer an attractive solution to lots of problems in many critical applications (Tadeusiewicz 2000). Moreover, Scardi (2001) shows as an effective alternative to conventional modelling techniques, and Paruelo and Tomasel (1997), Giraudel and Lek (2001), Pastor-Bárcenas et al. (2005), Kosiba and Stankiewicz (2007), Kosiba (2010) give some information on superiority of ANNs to various statistical methods, e.g. Principal
Component Analysis (PCA), Correspondence Analysis (CA), Polar Ordination (PO), Non-Metric Multidimensional Scaling (NMMS) and Hierarchical Clustering Analysis (HCA) in case of environmental and ecological studies.

We can see in literature, that the use of SOFM in ecology, also for description of water ecosystems are more and more used, rarely in case of areas and preserved plant and animal species. However, there are no such applications in case of ecological restoration and reintroduction/introduction of plant species.

The aim of the present work is to develop a SOFM model in order to examine and predict chemical site conditions and results of reintroduction/introduction of $A$. vesiculosa, and to demonstrate the ecological tolerance range of the species. To compare SOFM with the results of cluster analysis, and on the basis of cultivation in situ and ex situ of $A$. vesiculosa results putting forward the hypothesis: the SOFM is a usable neural network for assessment of chemical habitat conditions for reintroduction of the plant species. We expect that this tool could be used in identifying targets for water quality improvement.

\section{MATERIALS AND METHODS}

\section{Object of interest}

The object of interest was Aldrovanda vesiculosa L. (Fig. 1). Information on the species, among others on the history, systematic affiliation, biology, habitat requirements, number of sites and their distribution in Poland, reasons of disappearance, endanger status, conditions of reproduction and cultivation of the species in sterile in vitro cultures are included in papers by Kamiński (2006, 2008).

According to literature data the general number of natural sites in the world in 2005 was 51 , reintroduced ones 22 , out-of-date 138 and 115 sites requiring verification. In Poland, the data on number of $A$. vesiculosa sites and inventories revealed a high rate of disappearance of that plant, from 50 sites in 1958, 14 sites in 1986, to 9 sites of the beginning of the 90th. Whereas the numbers in 2005 were: 6 natural sites, 14 reintroduced, 78 out-of-date and 7 requiring verification (Kamiński 2006, and other papers cited here).

In accordance with Regulation of the Ministry of Environmental Protection in matter of wild growing and protected plants (Dz. U. nr 168, poz. 1764) by a strict protection included are all the carnivorous plants, to which also A. vesiculosa belongs. For works connected with reintroduction/introduction of the plant in situ obtained was the permission of the Ministry of Environmental Protection, Natural Resources and Forestry, see reprint of the permission in the paper by Kamiński (2006).

\section{Area and data of study}

The study area was Poland. Waters from fifty five sites were analysed in respect of chemical properties (Fig. 2). Archival data were used, and descriptions of habitats and plant communities are included in the paper by Kamiński (2006)

For marking the analysed sites and for the reason of the differentiated status of occurrence of $A$. vesiculos $a$ in those sites, we assumed to use the following marks (the use of the qualification natural sites concerns such water sites in 

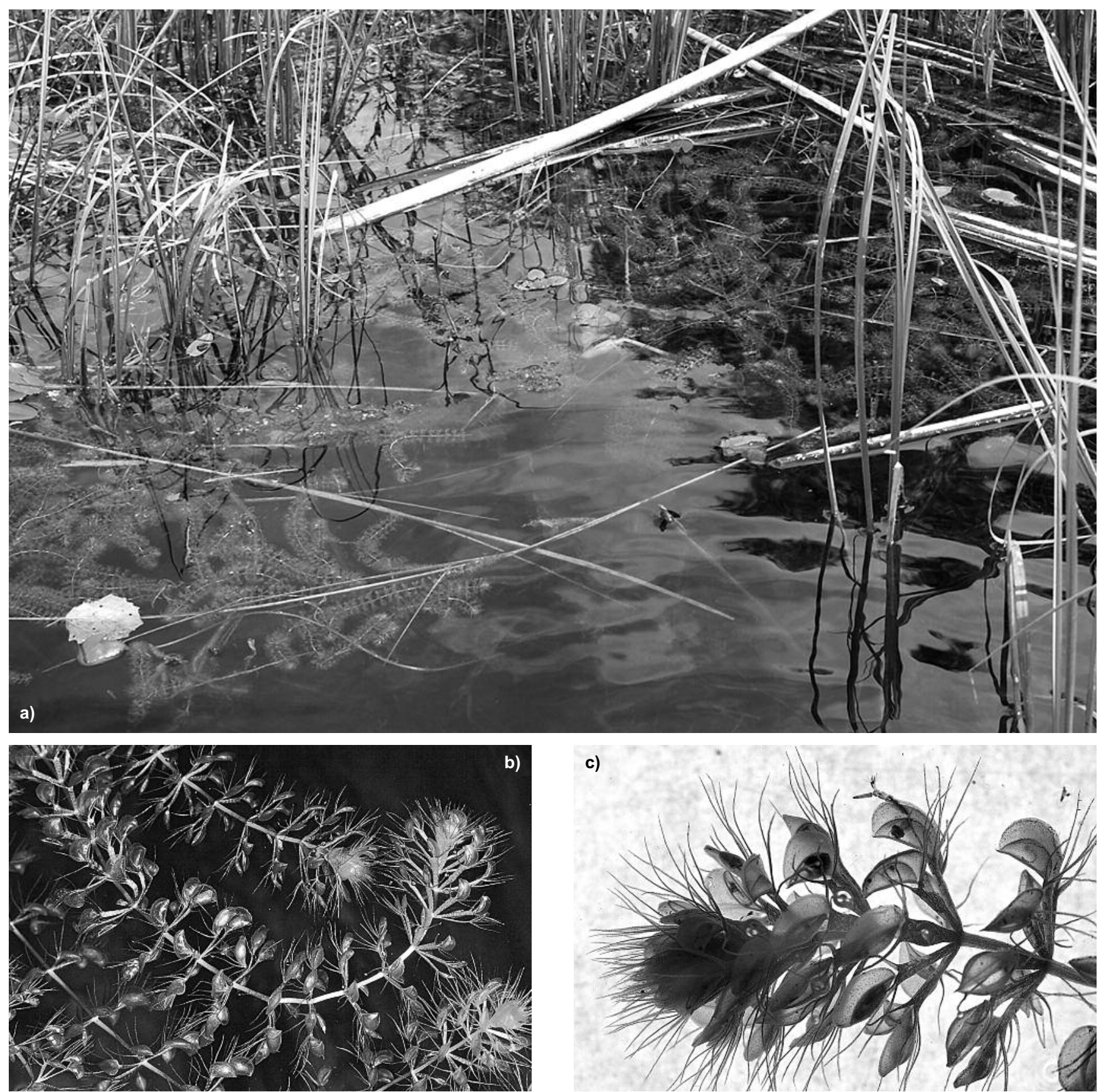

Fig. 1. Natural site of Aldrovanda vesiculosa (a), apical sections of stems with traps (b), traps with catched victims (c). (Pictures by R. Kamiński).

which the plant currently occurs or become extinct, the number of sites is given in brackets): AO (5) - natural sites of current occurrence of the plant, PR (13) - natural sites and replacements into which the plant had been reintroduced/introduced with positive result, $\mathrm{CH}$ (3) - cultivation sites of the plant in Botanical Garden in Wrocław, NO (7) - natural sites of out-of-date occurrence of the plant, NR (27) - natural and substitute sites, into which the plant had been reintroduced/introduced with negative result. We assumed that sites $\mathrm{AO}$ and $\mathrm{CH}$ represent optimal site conditions in situ and ex situ, for occurrence of A. vesiculos, respectively. We assumed that those sites are referential, i.e. sites of reference as regards the remaining analysed sites.

\section{Chemical analyses of water}

The water of sites was subject of chemical analyses and determined: the water reaction $(\mathrm{pH})$ and total hardness, as well as the contents of $\mathrm{N}-\mathrm{NH}_{4}, \mathrm{~N}-\mathrm{NO}_{3}, \mathrm{PO}_{4}^{-3}, \mathrm{~K}^{+}, \mathrm{Ca}^{+2}$, $\mathrm{Mg}^{+2}, \mathrm{Na}^{+}, \mathrm{Fe}^{+3}, \mathrm{Cl}^{-}$, and humic acids. In choice of these water components, among all the previously analysed, decisive was their rank in water classification in respect of trophicity. Detailed information on the preparation of water samples for analysis and the methods are presented in paper by Kamiński (2006).

\section{Statistical analyses}

On the basis of archival data, the results of water properties were expressed as arithmetic means, standard deviations $( \pm \mathrm{SD})$, minimum, maximum and variability coefficients $(\mathrm{V})$ values. The statistical analyses were performed: the empirical data were verified to the normal distribution by the Shapiro-Wilk's test, and the homogeneity of variances were checked up by Levene's test, and Kruskal-Wallis' rank test $(\mathrm{K}-\mathrm{W})$ were used. For ordering of sites used was 


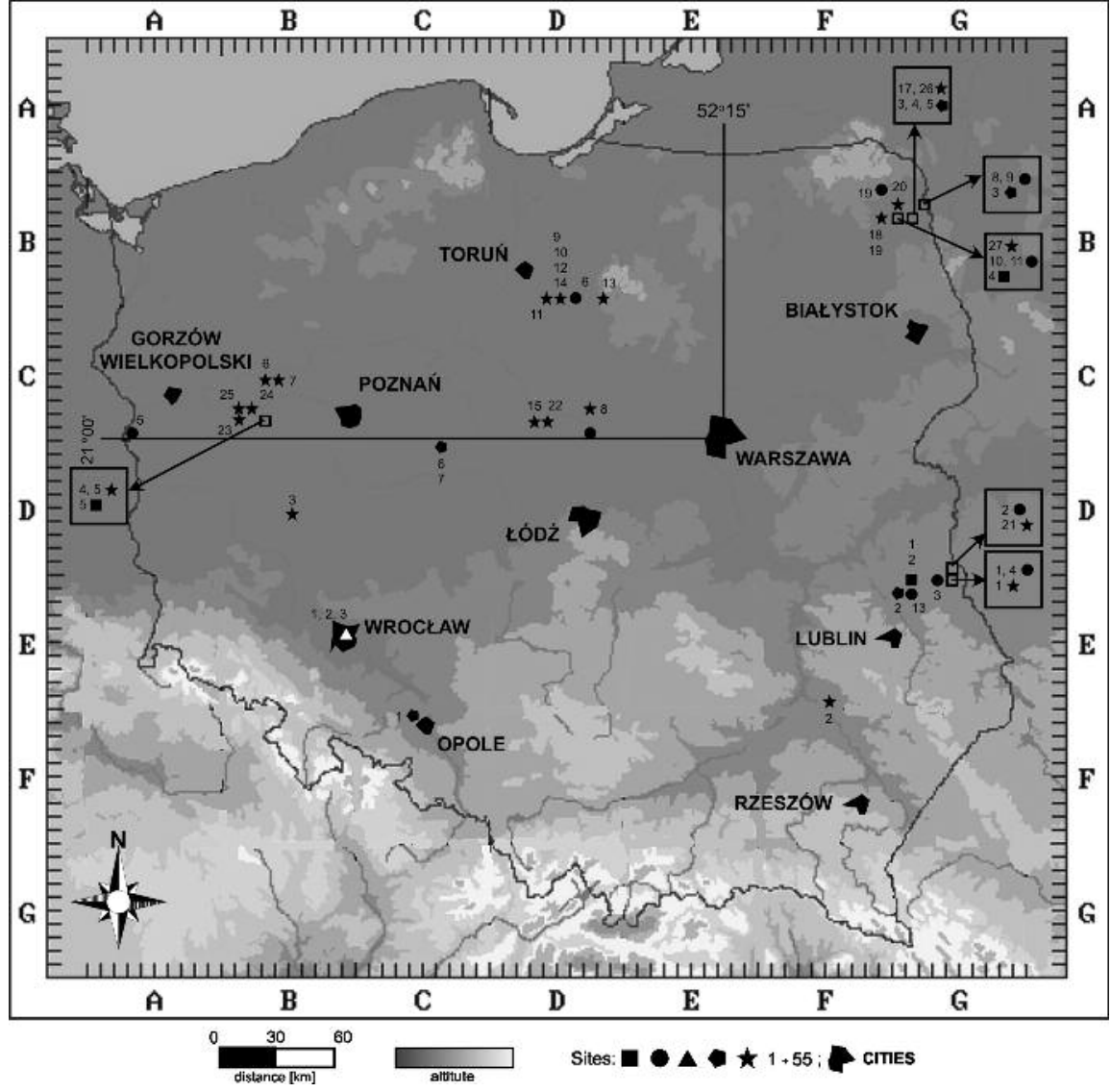

Fig. 2. Localization of the sampling sites of Aldrovanda vesiculosa in Poland.

(Notes: - AO 1, 2 (GE 01), 3 (GB 22), 4 (GB 30), 5 (BC 83), • PR 1 (GE 04), 2 (GD 94), 3 (GE 03), 4 (GE 04), 5 (AC 93), 6 (DB 96), 7 (DC 97), 8, 9 (GB 22), 10, 11 (GB 30), 12 (FB 19), 13 (GE 11), $\triangle \mathrm{CH} 1 \div 3$ (BE

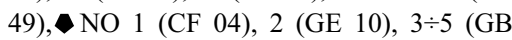
31), 6, 7 (CD 06), $\star$ NR 1 (GE 04), 2 (FE 95), 3 (BD 55) 4, 5 (BC 83), 6 (BC 53), 7 (BC 54), 8 (DC 17), 9, 10, 12, 14 (DB 95), 11 (DB 94), 13 (DB 98), 15 (DC 83), 16 (GB 20), 17, 26 (GB 31), 18, 19 (FB 39), 20 (GB 10), 21 (GD 94), 22 (DC 84), 23 (BC 81), 24 (BC 72), 25 (BC 71), 27 (GB 30) - symbols of sites, $1 \div 27$ - number of sites, more detailed description of symbols in chapter MATERIALS AND METHODS, Area and data of study, in parentheses localization of sites according to ATPOL atlas (Zając and Zając 2001)). the cluster analysis using Ward's method as distances between clusters (amalgamation) and Euclidean distance as distance measures $(\mathrm{x}, \mathrm{y})=\left\{\Sigma_{\mathrm{i}}\left(\mathrm{x}_{\mathrm{i}}-\mathrm{y}_{\mathrm{i}}\right)^{2}\right\}^{1 / 2}$. The ordination is presented by dendrograms. The significance of clusters has been determined on the basis of Sneath's index at $66.7 \mathrm{i}$ $33.3 \%$ of maximal distance (Dlink/Dmax)*100 and on the basis of the graph of amalgamation schedule.

For the artificial neural network the SOFM was used (Kohonen 2001) to classify the analysed sites in respect of trophicity status. The structure of the SOFM consists of two layers of neurons connected by weight (connection intensities). The input layer consisted of 55 input neurons (sites) and every neuron is represent by 13 analysed properties of water. On the basis of dataset and the classical Kohonen's algorithm the unsupervised training of the net was performed. The net was initiated by the random-Gaussian method. The learning phase has been broken down into 100 steps (EPOCHs) for the ordination phase and 1000 steps for the tuning phase. Finally, the Kohonen's network has been created in the form of a two-dimensional map. The Kohonen's topological map $8 \times 8$ has been designed visualized by tetragonal cells. Its output layer consisted of 64 neurons. The obtained Kohonen's topological map showed the neurons or groups of neurons activated by the particular investigated cases (sites).

The verification of the obtained results was carried out at significance level of 0.05 according to the statistical methods and principles given by Legendre and Legendre (1998) and Sokal and Rohlf (2003). For all calculations, the STATISTICA 9.0 program (StatSoft, Inc. 2009) was used.

\section{RESULTS AND DISCUSSION}

\section{Descriptive statistics and $K-W$}

It has been stated, that the investigated sites differ significantly between themselves in respect of the analyzed water properties $(\mathrm{K}-\mathrm{W}, \mathrm{p}<0.05)$ (Table 1$)$. The waters are characterized by a wide range of absolute values. The variability of water properties expressed by the variability coefficients is also high: for water reaction $10 \%$ and for the remaining properties from $33 \%$ (humic acids) to $140 \%\left(\mathrm{Cl}^{-}\right)$. The variability coefficients characterizes the relations of intensity of indirect reasons to main reasons (Zając 1994; Sokołowski 2010) and makes a good indicator in defining the degree of variability of traits. According to Krzywiecka (1989), the value of the variability coefficients up to $5 \%$ characterizes very good the trait's stability, instead $>15 \%$ inproperly (bad). In the analysed case the variability of water properties most often exceeds repeatedly the limit of $5 \%$ and several times the limit of $15 \%$ (twice for $\mathrm{pH}$, circa 30 times for $\mathrm{Cl}^{-}$and twice for humic acids to over 9 times for $\mathrm{Cl}^{-}$, respectively). On that basis one can state that the waters of the analysed sites are characterized by a low stability of all the investigated chemical components, expect the $\mathrm{pH}$ of a relatively low stability.

The results of $A$. vesiculosa reintroduction/introduction revealed that the populations of that plant species differ in cultivation effects, i.e. by a different abundance of occurrence, shapeliness and lack of remaining in the habitat (Kamiński 2006). Among the 40 sites selected for reintroduction/introduction of the investigated plant in 13 the cultivation gave positive effects. The results of chemical ana- 


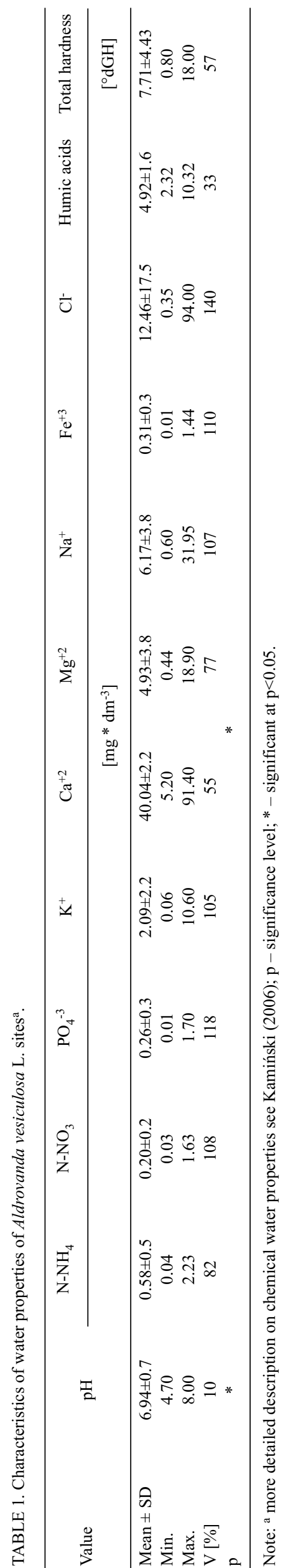

lyses of water showed on the one hand significant differences but on the other hand a similarity between the sites. This evidences a differentiated trophicity of the water. These results are confirmed by earlier investigations carried out by Vollenweider and Kerekes (1982), Wetzel (1983), Smith et al. (1999), Anderson et al. (2005). These authors unanimously ascertain that trophicity reflects the chemical composition of the water.

\section{Cluster analysis}

The cluster analysis allowed to detect the proper structure of waters in respect to chemical properties and to indicate the ordination of $A$. vesiculosa sites according to the accepted status (AO, PR, $\mathrm{CH}$, NO and NR). Accepted was the ordination of sites in two groups, A and B, of extremely distant similarity (Fig. 3).

The Sneath's index $66.7 \%$ arranges also the sites into two groups (A and B). Instead, the Sneath's index 33.3\% devides the group B, like the line of amalgamation schedule, into three subgroups B1,1 and B1,2 (group B1) and group B2. Extreme positions in the dendrogram are occupied by sites assigned to group A in relation to sites of group B2. This indicates to the least similarity of sites to each other. Group A arranges 20 sites of A. vesiculosa of status (in brackets the number of sites is given): AO (2), PR (9), CH (0), NO (2) and NR (7). However, group $\mathrm{B}$ arranges the remaining 35 sites of status: AO (3), PR (4), CH (3), NO (5) and NR (18). Comparing the proportional participation of sites with various occurrence status of $A$. vesiculosa between group $\mathrm{A}$ and $\mathrm{B}$, worthy of notice are the sites $\mathrm{AO}$ and $\mathrm{PR}$ from group $\mathrm{A}$, which make $61 \%$ (AO and PR) and $28 \%(\mathrm{NR})$ of the sites of such a status. The participation of sites with such a status in group B is different, and makes $39 \%$ (AO and PR) and 72\% (NR). The ordination of sites in respect of chemical properties of water, as well as the different proportional participation of proper and inproper sites for reintroduction/introduction $A$. vesiculosa between groups $\mathrm{A}$ and $\mathrm{B}$ indicates to a different type of water trophicity. Kamiński (2006), classifies sites of group A as dystrophic ( $\mathrm{AO}-2$ sites, $\mathrm{PR}-3$ sites, $\mathrm{NO}-$ 2 sites, NR -6 sites) and eutrophic shifted in the direction to dystrophicity (PR 6 sites, $\mathrm{NN}-1$ sites). An individuality make here the sites $\mathrm{CH}$, which in the dendrogram are distinctly separated from sites of group B. The unique localization of those three cultivation sites indicates, with a certain dose of caution, to a higher relation of them in respect of water chemical properties to sites of group A, then to sites of group B. Sites $\mathrm{CH}$ are classified as dystrophic (one site) and eutrophic ones (two sites). Moreover, the chemical properties of sites AO and PR from group A show a higher stability (Table 2). The ranges and mean values of variability indices are significantly lower for sites of group A in comparison with sites of group B. A similar lower variability is characteristic for sites NO and NR from group A and a higher one for sites of group B. Instead, the variability of water properties of sites $\mathrm{CH}$ is similar to variability of water ones from sites of group A. The results obtained from sites of group A and from cultivated sites of group B1,1 and B1,2 indicate the proper for reintroduction/introduction (cultivations ex situ) of A. vesiculosa and the type of water trophicity. The proper waters for occurrence and reintroduction/introduction of A. vesiculosa are eutrophic waters shifted in the direction to dystrophicity. Suitable, though in a lower degree, are dystrophic waters with a narrow range of chemical properties. According to earlier reports among others by Adamec (1998, 2005) and Kamiński (2006, and other papers cited here), the occurrence of $A$. vesiculosa is connected with oligo-, meso-, eu- and distrophic waters. These authors mention the range of ecological tolerance of this plant in respect of chemical properties of water. Current investigations and the listing of $A$. vesiculosa sites has shown that the occurrence of this plant is connected mainly with eutrophic to dystrophic waters (Kamiński 2006, 2008). The results of numerical analyzes of the present paper confirm the results obtained by the mentioned author, and show that the occurrence and cultivation of $A$. vesiculosa are most often connected with eutrophic shifted in the direction to dystrophicity waters. Moreover, the results indicate to a narrow range of ecological tolerance of $A$. vesiculosa in respect of water properties. A. vesiculosa is accepted as an eurytopic species, but on the basis of investigation results, as a stenotopic or relatively stenotopic species.

\section{Self-organizing feature map}

The SOFM was constructed to test the ordination of habitats in respect of chemical composition of water and for comparison with results of cluster analysis (Fig. 4). 


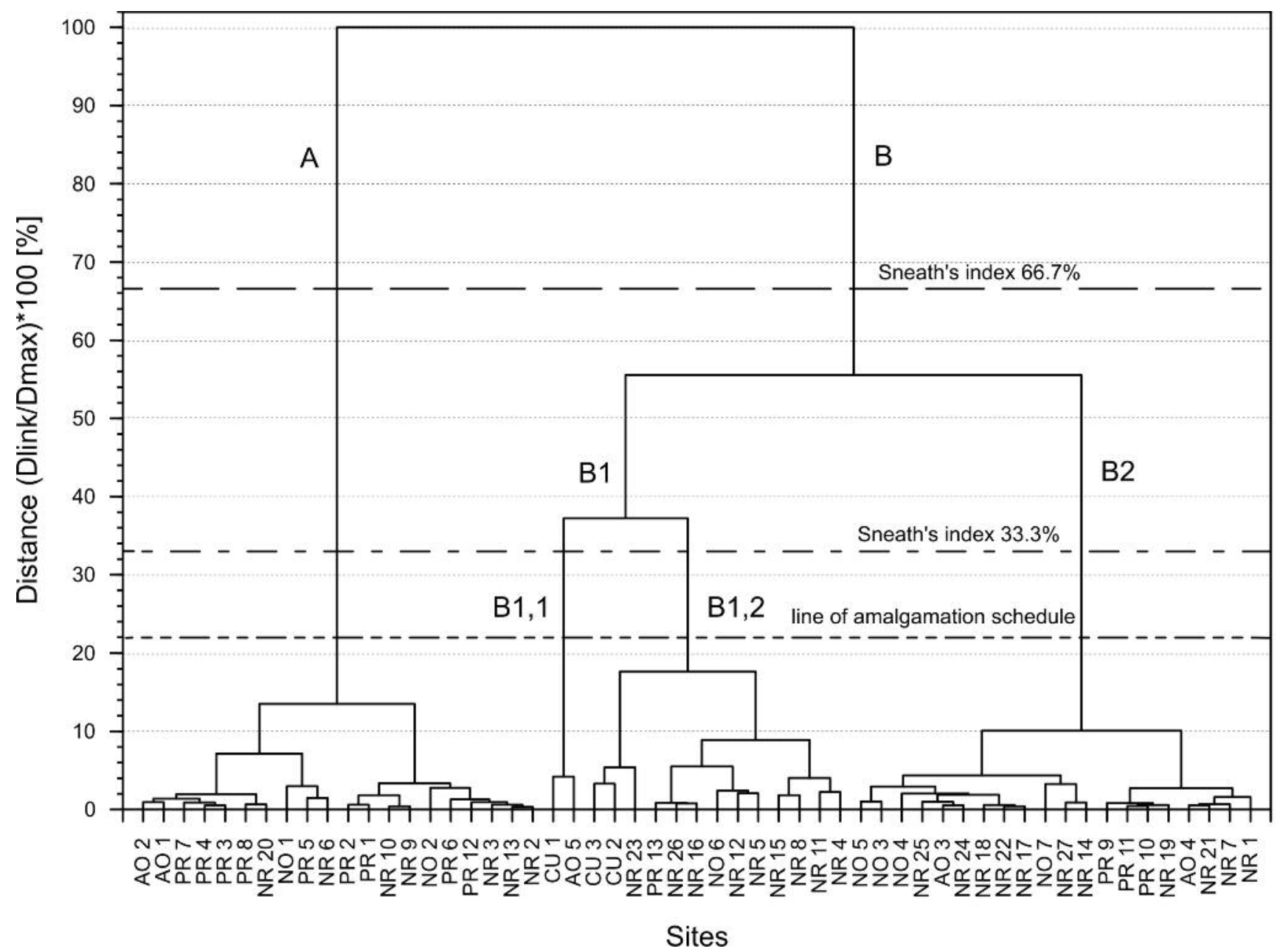

Fig. 3. Dendrogram of similarity of Aldrovanda vesiculosa sites.

(Notes: AO $1 \div 5$, PR $1 \div 13$, CH 1 $\div 3$, NO $1 \div 7$, NR $1 \div 27$ - symbols of sites, $1 \div 27$ - number of sites, more detailed description of symbols in chapter MATERIALS AND METHODS, Area and data of study).

TABLE 2. Variability coefficient values between groups of Aldrovanda vesiculosa L. sites in respect of water properties.

\begin{tabular}{|c|c|c|c|c|c|c|}
\hline \multirow{3}{*}{\multicolumn{2}{|c|}{ Water properties }} & \multicolumn{5}{|c|}{$\begin{array}{c}\mathrm{V} \\
{[\%]}\end{array}$} \\
\hline & & \multicolumn{2}{|c|}{ Group $\mathrm{A}^{\mathrm{a}}$} & \multirow{2}{*}{$\frac{\text { Group B1 }}{\mathrm{CH}^{\mathrm{b}}}$} & \multicolumn{2}{|c|}{ Group B ${ }^{\mathrm{c}}$} \\
\hline & & $\mathrm{AO}^{\mathrm{d}}$ and $\mathrm{PR}^{\mathrm{d}}$ & $\mathrm{NO}^{\mathrm{d}}$ and $\mathrm{NR}^{\mathrm{d}}$ & & $\mathrm{AO}^{\mathrm{d}}$ and $\mathrm{PR}^{\mathrm{d}}$ & $\mathrm{NO}^{\mathrm{d}}$ and $\mathrm{NR}^{\mathrm{d}}$ \\
\hline $\mathrm{pH}$ & & 8 & 13 & 3 & 5 & 11 \\
\hline $\mathrm{N}-\mathrm{NH}_{4}$ & & 51 & 89 & 31 & 79 & 83 \\
\hline $\mathrm{N}-\mathrm{NO}_{3}$ & & 39 & 149 & 47 & 67 & 109 \\
\hline $\mathrm{PO}_{4}^{-3^{3}}$ & & 51 & 94 & 31 & 155 & 116 \\
\hline $\mathrm{K}^{+}$ & 9 & 98 & 116 & 30 & 145 & 108 \\
\hline $\mathrm{Ca}^{+2}$ & 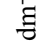 & 38 & 54 & 20 & 19 & 60 \\
\hline $\mathrm{Mg}^{+2}$ & * & 36 & 75 & 38 & 23 & 78 \\
\hline $\mathrm{Na}^{+}$ & $\Xi$ & 63 & 130 & 14 & 165 & 80 \\
\hline $\mathrm{Fe}^{+3}$ & & 79 & 115 & 46 & 95 & 115 \\
\hline $\mathrm{Cl}^{-}$ & & 72 & 86 & 38 & 178 & 80 \\
\hline Humic acids & & 22 & 36 & 74 & 16 & 31 \\
\hline Total hardness & 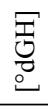 & 50 & 92 & 9 & 39 & 62 \\
\hline Mean \pm SD & & $51 \pm 24.9$ & $87 \pm 39.0$ & $32 \pm 19.3$ & $82 \pm 64.2$ & $78 \pm 33.0$ \\
\hline Min.-Max. & & $8-98$ & $13-149$ & $3-74$ & $5-178$ & $11-116$ \\
\hline
\end{tabular}

Note: ${ }^{\mathrm{a}, \mathrm{b}, \mathrm{c}}$ sites belong to groups A and B, more details see figure $3 ;{ }^{\mathrm{d}}$ more detailed description of symbols in chapter Materials and methods, Area and data of study. 
Neurons activated by actual occurence and positive cultivation results of $A$. vesiculosa sites group of distrophic

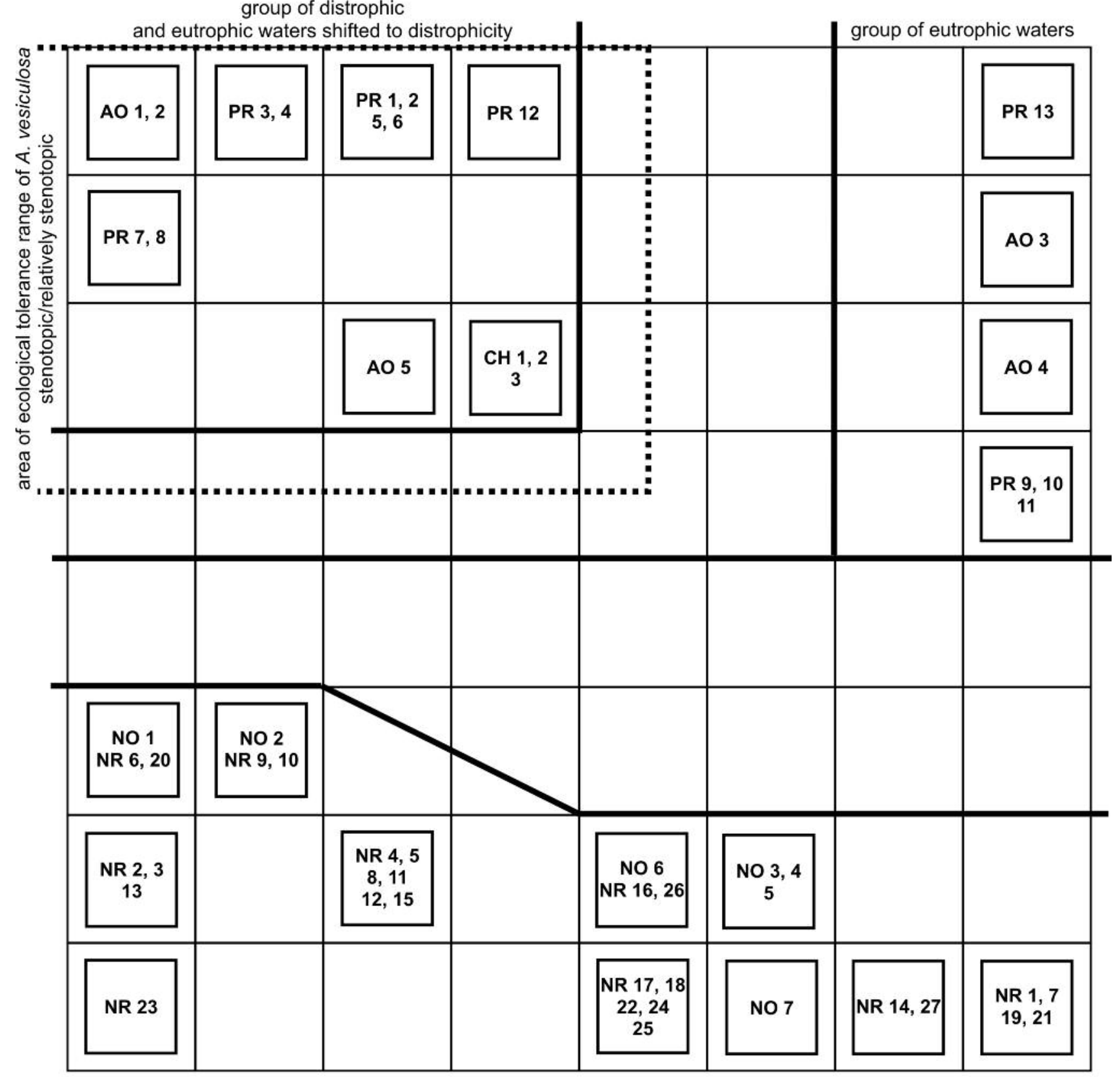

group of from mesotrophic up to dystrophic waters

Neurons activated by out-of-date occurrence and negative cultivation results of $A$. vesiculosa sites

Fig. 4. The 55 water sites of Aldrovanda vesiculosa mapped on the SOFM.

(Notes: AO $1 \div 5$, PR $1 \div 13$, CH 1 $\div 3$, NO $1 \div 7$, NR $1 \div 27$ - symbols of sites; $1 \div 27$ - number of sites, more detailed description of symbols in chapter MATERIALS AND METHODS, Area and data of study).

It was found that the sites in topological map (Fig. 4) show a characteristic ordination. In the resulting SOFM each cell represents a neuron. Sites within one neuron are the most similar and in neighboring neurons are more similar than sites in more distant neurons. The SOFM decidedly separates the particular sites, at the same time joining them into groups including the sites of highest similarity as regards both quantity and quality of the water properties. The map of the neural network clearly shows, that the natural (AO) and reintroduced/introduced sites (PR) of $A$. vesiculosa are grouped together or take neighbouring positions. That group eutrophical-distrophical sites is distinctly separated from the remaining sites (groups and individual sites) of out-of-date occurrence of the plant (NO) and a negative cultivation result of $A$. vesiculosa (NR). Their trophic characterization contains waters from mesotrophic up to dystrophic ones, yes their considerable part corresponds with various transitional types of waters' trophicity. Worthy of notice is the neighbourhood and close neighbourhood of the ordinated on the topological map of cultivation sites $(\mathrm{CH})$. Their localization indicates to the higher similarity in relation to natural and sites with positive reintroduction/introduction results (AO and PR).

Amalgamation of sites presented in the dendrogram (Fig. 3 ), constructed by means of cluster analysis is in significant degree similar to ordination of them obtained by 
SOFM model (Fig. 4). Sites AO and PR take up the same group A in the dendrogram (Fig. 3) on the Kohonen's map occupying individual neurons, but in close neighbourhood (Fig. 4), which are localized on the left of the center. However, there is no ordination of sites NO and NR, which is visible in the dendrogram (Fig. 3). The ordination of sites $\mathrm{AO}$ and PR in the dendrogram and in the SOFM model groups together waters of similar trophicity type and lower variability of chemical parameters (Table 2). Opposite to group A is group B (Fig. 3) with sites of A. vesiculosa of different trophicity type of water, which corresponds with the group of neurons on the opposite margin of the topological map, on the right of the center of SOFM (Fig. 4). The ordination of these sites shows the passway from humic-eutrophic waters through eutrophic, in eutrophic shifted to distrophic up to dystrophic ones and is characterized by a higher variability of chemical properties of water (Table 2). In these sites $A$. vesiculosa dose not occur and cultivation has not produced the expected results. Also here the neurons activate few sites without $A$. vesiculosa of status NO (two dystrophic sites) and NR (one eutrophic site shifted to dystrophicity), which belong to group A in the dendrogram (Fig. 3). Near the center of Kohonen's map activated are neurons by three cultivation sites $(\mathrm{CH})$. Their neighbourhood in relation to neurons activated by the remaining sites is closer to neurons of sites AO and PR. The sites $\mathrm{CH}$ are in respect of trophicity type eutrophicdistrophic of similarly low variability of chemical properties, like in case of water from sites AO i PR (Table 2).

The cluster analysis and the SOFM model demonstrated a similar ordination of $A$. vesiculosa sites of various status of occurrence of that plant, their chemical properties and trophicity type. Worthy of notice are the differences in arrangement of sites NO and NR, which the localization in SOFM (Fig. 4) is different in relation to the position in the dengrogram (Fig. 3). Despite the fact that sites NO and NR are characterized by approximale properties and trophicity type in relations to sites AO and PR from group A in dendrogram, they differ by a wider range of variability of water properties in relation to sites $\mathrm{AO}$ and $\mathrm{PR}$. This points to the factor decisive on lack of occurrence of $A$. vesiculosa in these three sites (NO - two sites and NR - one site). Such cases occur frequently in nature sites, as here we have to do with a complex of biotic and abiotic factors of the environment, among others, by: the complex of microclimatic, physical, chemical, biological processes, as well as those of the basic-water arrangement (Gümrah et al. 2000; Karul et al. 2000; Ha and Stenstrom 2003).

Moreover, the topological map (Fig. 4) more than the dendrogram (Fig. 3) show a range of ecological tolerance of $A$. vesiculosa in respect to water properties, here trophicity. This species of plant is able to adapt to a narrow range of water properties and occur mainly in eutrophic waters shifted to dystrophic, seldom in dystrophic and more so in eutrophic ones.

According to Weigleb (1981), Roy et al. (1992) and Roman et al. (2001) and Kosiba (2004) the identification of water chemical composition makes the grounds for indentification of ecological water types and confirms the ecological formations of different water plant species in respect to water chemistry. Thus, the analysed sites belong to different types of water in respect of their chemical properties. Hence, this makes the ground for identification of ecologi- cal formations of different plant species, and gives the knowledge on trophic requirements and ecological tolerance of plants. Plant species characterized with wide ecological tolerance range can survive in highly differentiated waters in respect of chemical properties, which in case of A. vesiculosa has not been ascertained. The results of the investigations showed a narrow range of $A$. vesiculosa ecological tolerance in relation to habitat conditions, also disappearance of the plant species and confirm the results obtained by Purvis et al. (2000). These authors showed on the basis of the comparative studies that the stenotopic species have a far greater tendency to become extinct than eurytopic ones, what is also presented in the study.

Several machine-learning methods have been used to interpret and classify the water reservoirs into quality classes. For example Walley et al. (2000), Aquilera et al (2001) and Kosiba and Stankiewicz (2007) classify biological and chemical data to diagnose water quality. These authors communicate, that the chemical properties give a specific picture of water quality and stress the importance of biological methods for monitoring water quality. In this study SOFM mapping was demonstrated in patternizing water trophicity communities in ecological data. Through conventional statistical methods, clustering analysis, the grouping of habitats is possible, however, it only represents the degree of association among communities. The Kohonen's network allows not only grouping, but makes possible to patternize new data by assigning a new component. Chon et al. (1996) show that this may be especially helpful in comprehensive understanding of data in ecology. Similar comparative techniques with use of SOFM and classical statistical methods (PCA, PO, CoA, NMDS) were applied, among other by Giraudel and Lek (2001) for ordination of ecological community, Lee and Scholz (2006) for assessment of SOFM as an alternative method, performance indicators, for constructed treatment of wetlands with respect to k-nearest neighbors (KNN) and support vector machine (SVM), by Samecka-Cymerman et al. (2007), who used SOFM and PCA as a tool in classification of the relation between chemical composition of aquatic bryophytes and streambeds or by Kosiba (2010) in bioindication and population studies. These authors prove the importance of SOFM and recommend it as a good tool in ecological modelling, which can be used in various fields of applied ecology. Our study has shown that the SOFM model is in a considerable degree similar to the results of cluster analysis used for classification of water sites in respect of trophicity, in estimation of chemical properties of water in reintroduction/introduction, the range of ecological tolerance and the occurrence of $A$. vesiculosa, what is confirmed in the present study.

\section{CONCLUSIONS}

1. Ordination of sites in SOFM model is in a large degree concordant with the amalgamation of cluster analysis. Both methods show differences of Aldrovanda vesiculosa sites in respect of water trophicity. The preferred sites (habitats) for occurrence of that plant species are eutrophic waters shifted to dystrophicity, rarely distrophic ones. 
2. The results of SOFM and cluster analysis are similar, but not identically. SOFM can help to discover hidden relationships within waters' data that may not be easily observed because of the highly complex interactions occurring within the water. The SOFM model indicated with precision of the proper environmental conditions for reintroduction/introduction and cultivation of Aldrovanda vesiculosa, moreover, to the ecological tolerance range of this species in respect of trophicity, i.e. stenotopic/relatively stenotopic towards the earlier accepted its eurytopic status.

3. The SOFM is an effective means of modelling both quantitative and descriptive water properties and can be used as a simulation tool to predict (and forecasting) the type of water for ecological restoration and reintroduction/introduction conditions of water plants.

4. This study shows that models can be derived using SOFM as a viable modelling technique.

\section{LITRERETURE CITED}

ADAMEC L. 1998. Will the rare aquatic carnivorous plant Aldrovanda vesiculosa survive in Europe? Manuscript. Published in Dutch. WAP-krant (Dutch Waterplant Society, Gravenhage, NL), 104: 12-14.

ADAMEC L. 2005. Ten years after the introduction of Aldrovanda vesiculosa to the Czech Republic. Acta Bot. Gallica, 152: 239-245.

ANDERSON N.J., JEPPESEN E., SØNDERGAARD M. 2005. Ecological effects of reduced nutrient loading (oligotrophication) on lakes: an introduction. Freshwater Biology, 50, 10: 1589-1593.

AQUILERA P.A., FRENICH A.G., TORRES J.A., CASTRO H., VIDAL J.L.M., CANTON M. 2001. Application of the Kohonen neural network in coastal water management: methodological development for the assessment and prediction of water quality. Water Res., 35, 17: 4035-4062.

BELL J.N.B., TRESHOW M. 2002. Air pollution and plant life. John Wiley \& Sons, Inc., Chichester.

CHON T., PARK Y.S., MOON K.H., CHA E.Y. 1996. Patternizing communities by using an artificial neural network. Ecol. Model., 90: 69-78.

COLASANTI R.L. 1991. Discussions of the possible use of neural network algorithms in ecological modelling. Binary, 3: 13-15 .

DZIENNIK USTAW RP nr 186, poz. 1764. Rozporządzenie Ministra Środowiska z dnia 9 lipca 2004 r. w sprawie gatunków dziko występujących roślin objętych ochroną. (in Polish)

EDWARDS M., MORSE D.R. 1995. The potential for computeraided identification in biodiversity research. Trends Ecol. Evol., 10, 4: 153-158.

GIRAUDEL J.L., LEK S. 2001. A comparision of self-organizing map algorithm and some conventional statistical methods for ecological community ordination. Ecol. Model., 146: 329-339.

GÜMRAH F., ÖZ B., GÜLER B., EVIN S. 2000. The Application of Artificial Neural Networks for the Prediction of Water Quality of Polluted Aquifer. Water Air \& Soil Pollution, 119: 275-294.

HA H., STENSTROM M.K. 2003. Identification of land use with water quality data in stormwater using a neural network. Water Res., 37: 4222-4230.

HECHT-NIELSEN R. 1990. Neurocomputing. Addison-Wesley Publishing Company, Readings.

HUTCHINSON E.G. 1975. A treatise on limnology. Vol. III, Limnological botany, John Wiley and Sons, New York-London-Sydney-Toronto.
KAMIŃSKI R. 1995. Reintrodukcja Aldrovanda vesiculosa L. na Pojezierzu Łęczyńsko-Włodawskim. Acta Univ. Wratislaviensis, No. 1807, Prace Bot., 67: 157-166. (in Polish with English summary)

KAMIŃSKI R. 2006. Restytucja aldrowandy pęcherzykowatej (Aldrovanda vesiculosa L.) w Polsce i rozpoznanie czynników decydujących o jej przetrwaniu w klimacie umiarkowanym. Prace Ogrodu Botanicznego Uniwersytetu Wrocławskiego, 8, 11: pp. 105. (in Polish with English summary)

KAMIŃSKI R. 2008. Aldrowanda pęcherzykowata Aldrovanda vesiculosa L. In: Monitoring gatunków i siedlisk przyrodniczych ze szczególnym uwzględnieniem specjalnych obszarów ochrony siedlisk Natura 2000. Metodyka monitoringu - Przewodniki metodyczne. GIOŚ, 1516, pp. 1-14. (in Polish)

KARUL C., SOYUPAK S., CILESIZ A. F., AKBAY N., GERMAN E. 2000. Case studies on the use of neural networks in eutrophication modeling. Ecol. Model., 134: 145-152.

KAŹMIERCZAKOWA R., ZARZYCKI K. (eds). 2001. Polska Czerwona Księga Roślin. Praca zbiorowa. PAN, Instytut Botaniki im. W. Szafera, Instytut Ochrony Przyrody, Kraków. (in Polish with English summary)

KOHONEN T. 2001. Self-Organizing Maps, 3rd ed. SpringerVerlag, Berlin, Heidelberg, New York.

KOSIBA P. 2004. Chemical properties and similarity of habitats of Utricularia species in Lower Silesia, Poland. Acta Soc. Bot. Pol., 73, 4: 335-341.

KOSIBA P. 2010. Modele ekologiczne reakcji wybranych gatunków mchów endohydrycznych na oddziaływanie zanieczyszczeń przemysłowych. Badania bioindykacyjne i populacyjne. Wydawnictwo Uniwersytetu Wrocławskiego, Wrocław, pp. 121. (in Polish with English summary)

KOSIBA P., STANKIEWICZ A. 2007. Water trophicity of Utricularia microhabitats identified by means of SOFM as a tool in ecological modelling. Acta Soc. Bot. Pol., 76, 3: 255-261.

KRZYWIECKA M. 1989. Przewodnik do ćwiczeń ze statystyki matematycznej. Skrypt AR we Wrocławiu, Nr 347. (in Polish)

LEE B.H., SCHOLZ M. 2006. A comparative study: Prediction of constructed treatment wetland performance with k-nearest neighbors and neural networks. Water, Air \& Soil Pollution, 174: 279-301.

LEGENDRE P., LEGENDRE L. 1998. Numerical ecology. 2nd English edition. Elsevier Science BV, Amsterdam.

LEK S., GUÉGAN J.F. 1999. Artificial neural networks as a tool in ecological modelling, an introduction. Ecol. Model., 120: 65-73.

MIREK Z., ZARZYCKI K., WOJEWODA W., SZELĄDG Z. (eds). 2006. Czerwona lista roślin i grzybów Polski. Instytut Botaniki PAN, Kraków. (in Polish with English summary)

ÖZEMI S.L., TAN C.O., ÖZESMI U. 2006. Methodological issues in building, training, and testing artificial neural networks in ecological applications. Ecol. Model., 195: 83-93.

PARUELO J.M., TOMASEL F. 1997. Prediction of functional characteristics of ecosystems: a comparision of artificial neural networks and regression models. Ecol. Model., 98, 2-3: 173-186.

PASTOR-BÁRCENAS O., SORIA-OLIVAS E., MARTINGUERRERO J.D., CAMPAS-VALLS G., CARRASCO-RODRIGUEZ J.L., DEL VALLE-TASCÓN S. 2005. Unbiased sensitivity analysis and pruning techniques in neural networks for surface ozone modeling. Ecol. Model., 182: 149-158.

PULLIN A.S. 2002. Conservation biology. Cambridge University Press, Cambridge, pp. 284-304.

PULLIN A.S., STEWART G.B. 2006. Guidelines for systematic review in conservation and environmental management. Conserv. Biol., 20: 1647-1656.

PURVIS A., JONES K.E., MACE G.M. 2000. Extinction. Bioessays, 22: 1123-1133.

ROMAN C.T., BARRETT N.E., PORTNOY J.W. 2001. Aquatic vegetation and trophic condition of Cape Cod (Massachusetts, U.S.A.) kettle ponds. Hydrobiologia, 443: 31-42. 
ROY S., IHANTOLA R., HANNINEN O. 1992. Peroxidase activity in lake macrophytes and its relation to pollution tolerance. Environ. Exp. Bot., 32, 4: 457-464.

SAMECKA-CYMERMAN A., STANKIEWICZ. A., KOLON K., KEMPERS A.J. 2007. Self-organizing feature map (neural networks) as a tool in classification of the relations between chemical composition of aquatic bryophytes and type of streambeds in the Tatra national park in Poland. Chemosphere, 67, 5: 954-960.

SCARDI M. 2001. Advances in neural network modeling of phytoplankton primary production. Ecol. Model., 146: 33-45.

SMITH V.H., TILMAN G.D., NEKOLA J.C. 1999. Eutrophication: impacts of excess nutrient input of freshwater, marine, and terrestrial ecosystems. Environ. Pollut., 100: 179-196.

SOKAL R.R., ROHLF F.J. 2003. Biometry. The principles and practice if statistics in biological research. W. H. Freeman And Company, New York.

SOKOŁOWSKI A. 2010. Estymacja i testowanie hipotez, In: Statistica w badaniach naukowych i nauczaniu statystyki. StatSoft Polska Sp. z o.o., Kraków, pp. 25-60. (in Polish)

STATSOFT, INC. 2009. STATISTICA (data analysis software system), version 9.0, StatSoft, Inc., Tulsa, OK, USA, (www. statsoft.com).

TADEUSIEWICZ R. 1993. Sieci neuronowe. Akademicka Oficyna Wydawnicza, Warszawa. (in Polish)

TADEUSIEWICZ R. 1998. Elementarne wprowadzenie do sieci neuronowych z przykładowymi programami. Akademicka Oficyna Wydawnicza, Warszawa. (in Polish)
TADEUSIEWICZ R. 2000. The application of neural networks in biotechnology and biomaterials. Prace Miner., 89: 9-17.

VOLLENWEIDER R.A., KEREKES J. 1982. Eutrophication of waters. Monitoring, assessment and control. OECD Cooperative programme on monitoring of inland waters (Eutrophication control), Environment Directorate, OECD, Paris.

WALLEY W.J., MARTIN R.W., O'CONNOR M.A. 2000. Selforganizing maps for the classification and diagnosis of river quality from biological and environmental data, In: R. Denzer, D.A. Swayne, M. Purvis G. Schimak (eds), Environmental Software System: Environmental Information and Decision Support, Kluwer, Dordrecht, pp. 27-41.

WETZEL R.G. 1983. Limnology. Saunders College Publishing, Philadelphia, PA, USA.

WIEGLEB G. 1981. Application of multiple discriminant analysis of the correlation between macrophyte vegetation and water quality in running waters of central Europe. Hydrobiologia, 79: 91-100.

ZAJĄC K. 1994. Zarys metod statystycznych. PWE, Warszawa. (in Polish)

ZAJĄC A., ZAJĄC M. (eds). 2001. Distribution atlas of vascular plants in Poland. Edited by Laboratory of Computer Chronology, Institute of Botany, Jagiellonian University, Cracow.

ZARZYCKI K., WOJEWODA W. 1986. Lista roślin wymierajacych i zagrożonych w Polsce. Komitet Ochrony Przyrody i Instytut Botaniki PAN, PWN, Warszawa. (in Polish with English summary) 